likely to lead to new ideas on the use of insecticides. An investigation of the mechanism of water control in the pupa of Glossina is contributing to an understanding of the success and failure of some current methods of reclamation.

At the Sukulu Laboratory a small hospital was opened for the reception of patients from the lakeshore fly-belts, and a joint investigation with the Kenya Medical Department has shown that in that area $G$. pallidipes is a carrier of $T$. rhodesiense. The epidemiology of palpalis-borne sleeping sickness in Uganda is also being investigated. In Northerm Rhodesia trypanosomiasis research has been limited to drug trials and prophylaxis. The Veterinary Department of the Northern Region of Nigeria is pursuing a vigorous programme of research into cattle trypanosomiasis, while the Department of Veterinary Services, Tanganyika, has compared the protection given by prothidium, ethidium-suramin complex and $R D 290$ suramin complex with that given by 'Antrycide' prosalt. Prothidium was also the outstanding new prophylactic tested by the Department of Veterinary Services, Kenya.

The report of the director of the Anti-Locust Research Centre for 1956-57-in which the Centre received 984 reports of the desert locust situation from thirty-two territories, including reports on lowdensity locust populations from survey officers in the
Somali Peninsula, Ethiopia and parts of Arabianotes that the desert locust situation improved somewhat in Eastern Africa, Iran, Pakistan and India, although heavy breeding occurred in the Sudan, the French Chad territory and the Niger Colony. A panel of international experts which met at the Anti-Locust Research Centre in April 1956 recommended that permanent surveys of the whole of the distribution area should be established by all governments concerned, and that all information on the state of desert locust populations and relevant weather phenomena should be centralized.

The Intermational Red Locust Control Service continued studies on red locust populations in relation to vegetation dynamics and on control methods, and the International African Migratory Locust Organization became a permanent international body in 1956, when a research service was established. The Anti-Locust Research Centre continued to work on phase variation and its inheritance ; maturation and fecundity in the red locust; weight and water-content of the desert locust in relation to flight and the life-cycle of Eyprepocnensis plorans, Acrida bicolor and Gastrinargus africanus. Annual and seasonal frequency maps of the incidence of desert locust swarms and hoppers were completed and maps of the major seasonal swarm movements were prepared.

\title{
OBITUARIES
}

\section{Dr Willis R. Whitney}

Wrre the death on January 9 of Dr. Willis Rodney Whitney, at the age of eighty-nine, there ended a very remarkable career.

Although Dr. Whitney was a first-class scientist in his own right, his great contribution was the organization and successful direction, for thirty-two years, of the Research Laboratory of the General Electric Co., Schenectady, New York. It is hard to understand now what a truly pioneer task this was, for in 1900 there were no organized industrial research laboratories in the United States. He had to prove that industrial research could be made to pay. When he did this, other industries quickly followed General Electric's example. To-day, a research laboratory is considered essential for industrial success.

Born in Jamestown, New York, on August 22, 1868, Dr. Whitney's interest in science began with the acquisition of a microscope when he was in high school. After graduating from the Massachusetts Institute of Technology in 1890, he first spent four years as instructor in chemistry there, then went to the University of Leipzig, where he received his Ph.D. degree in 1896. After six months at the Sorbonne, he returned to the Massachusetts Institute of Technology as assistant professor and later full professor.

It was at this point that $\mathbf{E}$. W. Rice, vice-president of the General Electrio Co., visited him and proposed that he should start a research laboratory -a thing new to industry. The fact that it was an experiment appealed to Whitney - he loved an experiment. But he also believed in proceeding cautiously and slowly, feeling one's way. So he agreed to try it on a parttime basis, spending three days a week in Schenectady and the other three at the Massachusetts Institute.
His first laboratory was a barn in the rear of Dr. Steinmetz's house, and the laboratory staff consisted of Whitney and half the time of an assistant shared with Dr. Steinmetz. When the barn burned down in the following year, he moved to a building in the Schenectady works, and gradually began to add more employees, being very careful to preserve the atmosphere of friendly co-operation.

This atmosphere he himself generated by personal example. As long as the size of the laboratory permitted, he made a practice of visiting every member of the staff every day. His usual greeting on these visits was, "Are you having any fun ?". To him, research was fun, "the finest of sports", as he once expressed it. Frequently, on his visits, he brought some new project or experiment, suggested by company activities or scientific progress, which he literally peddled from room to room, but seldom assigned.

It was one of his key principles that members of his staff were given freedom, in proportion to their proved ability, to choose their own research problems, and to publish important results promptly in their own names. He was a pioneer in the championing of such publication.

Optimism, enthusiasm and sound judgment were conspicuous qualities of Dr. Whitney, but above all was his devotion to science. It was literally true of him that science was his religion. He often talked about religion, but always concluded that the "search for truth" was the best kind of religion.

Scientific curiosity, which he once defined as the greatest asset of a research man, was his most conspicuous quality. If you visited him on a Saturday afternoon, you were likely to find him in a field near his home, putting a small piece of iron wire in the stem of a golden-rod and surrounding it by a highfrequency coil, to find out whether it was the heat of 
the bug inside that caused the swelling called a gall to grow. Or you might find him sitting on a log in the woods, counting the mosquitoes that alighted on him and on a quarter of beef beside him, to find out how they knew what to bite.

Dr. Whitney retired as director in 1932, becoming an honorary vice-president of the General Electric Co. But he still came to the laboratory every day, at first devoting his time to personal experiment, his first love, which he had missed during his directorship; and later to visiting the research workers, with interest and encouragement.

Dr. Whitney's success as a pioneer of industrial research is a lasting contribution. The secret of that success was a combination of remarkable personal qualities - friendliness, mental vigour, breadth of interest and knowledge, stimulating originality, delightful flashes of humour, modesty, courage, directness and simplicity.

A. W. HULL

\section{Dr. K. H. Barker}

DR. K. H. BARKER, who died suddenly in London on March 3, was born in Manchester in 1925 and educated in the Department of Physics at the University of Manchester, graduating in 1948. His university education was interrupted between 1945 and 1947 when he worked on the Tube Alloys Project in the Department of Physics at the University of Liverpool.

In 1948 Barker started research work in cosmicray physics at Manchester, under the direction of Prof. P. M. S. Blackett. At the beginning of his research career he joined my group, then engaged in studying high-energy nuclear collisions using a cloud chamber equipped with an electromagnet. This collaboration lessted until his death, a period of almost ten years without a break. His death is a very great loss to the group and to the subject of highenergy nuclear physics in which he had achieved a world-wide reputation.

The Manchester electromagnet was moved to the Observatory on the Pic-du-Midi in the French
Pyrenees in the autumn of 1949. Barker was responsible for installing the magnet and cloud chamber in the mountain laboratory at an altitude of $9,500 \mathrm{ft}$. Altogether, he spent between two and three years of his life working with the apparatus. In the early years he often climbed to the mountain top during the winter months; but a cable railway has now been installed. Barker was a first-class experimental physicist able to operate and maintain efficiently a complicated piece of equipment in very difficult circumstances.

In 1950 Barker obtained a very valuable set of photographs showing many decays of $V^{0}$-particles. From the analysis of these pictures the group demonstrated, for the first time, that the $V^{0}$-particles, discovered by Rochester and myself in 1947, consisted of two kinds: neutral $\Lambda$-hyperons which are heavier than the proton and heavy mesons, with mass intermediate between the $\pi$-meson and the proton. Barker played a leading part in obtaining and interpreting these photographs. He also observed, in 1950, the first decay of a $\Xi$-hyperon.

In 1953 Prof. Blackett and a number of his staff moved from Manchester to the Imperial College of Science and Technology, London. Barker was at once appointed a lecturer in physies at the Imperial College and continued to spend part of his time at the Pic-du-Midi working on the same general research programme. During the past year or so the group has been studying the properties of nucleon-nucleon collisions with energies of $50 \mathrm{GeV}$. and upwards. In this work Barker collaborated very successfully and fruitfully with French physicists from Prof. LeprinceRinguet's Laboratory at the Ecole Polytechnique in Paris. At the time of his death he was enthusiastically planning new experiments in high-energy nuclear physics using an accelerator, instead of the cosmicrays, as a source of particles.

Barker was a good teacher, both of undergraduates and research students, and, as a friendly and helpful colleague, will be sadly missed by the staff of the Department of Physics at the Imperial College.

C. C. Butler

\section{NEWS and VIEWS}

\section{Mastership of Clare College, Cambridge : \\ Sir Henry Thirkill, C.B.E.}

Sir Henry Thirkill retires from the mastership of Clare College, Cambridge, on September 30 next. Apart from the war years 1914-19, Sir Henry has been in residence since he entered the College as an undergraduate in 1905. $\mathrm{He}$ sat for the Natural Sciences Tripos, Part I, in 1907, and for Part II in the following year. He was elected a Fellow of Clare in 1910 , having embarked on research at the Cavendish Laboratory under J. J. Thomson, being later one of his demonstrators in the somewhat precarious days when the professor was personally responsible for his assistant's stipends. During the First World War, Thirkill served in the Royal Engineers, being O.C. Wireless in East Africa, 1915-18, and receiving the Military Cross. On returning to Cambridge, he was appointed College lecturer and a University lecturer in experimental physics. It is, however, as tutor of Clare College from 1920 that he will best be remembered by many generations of Clare men--not only for his gentle if determined guidance but also for his hospitality at breakfast or Sunday evening music and, for the more energetic, on the tennis or squash court. Though made president of the College in 1930, he retained the tutorship until he was elected master in 1939.

Always a great worker, Thirkill found time from an early date to serve the University as well as his College. He was elected a member of the Council of the Senate so far back as 1927, serving continuously for thirty years. This was only a beginning; for many years he was also a member of the General Board of the Faculties, of the Financial Board and of many other committees. It would be difficult to find a man in any age who has given longer or more devoted service in the sometimes thankless task of university administration. Thirkill was vice-chancellor in the particularly busy years 1945-47 when plans for post-war developments were being prepared on every hand. It fell to him to entertain the many war leaders on whom honorary degrees were conferred. His brilliant speeches at the 